\title{
When two pandemics meet
}

\author{
Tamara Daniela Frydman ${ }^{1} 1$, Natalie Madeline Atkinson-Ginsburg ${ }^{2}$ and Melchor Alpízar-Salazar (D)1 \\ ${ }^{1}$ Specialized Center for Diabetes, Obesity and Cardiovascular Disease Prevention, S.C. \\ ${ }^{2}$ American British Cowdray Medical Center
}

${ }^{\star}$ Corresponding author: Melchor Alpízar-Salazar MD, PhD; FACE; Mexico City, Mexico; E-mail: melchoralpizar@gmail.com

Received: May 04, 2020; Accepted: May 14, 2020; Published: May 20, 2020

\begin{abstract}
The COVID-19 pandemic has emerged in the middle of another pandemic which is far from under control: the cardiometabolic syndrome pandemic. Recently published data suggests patients with obesity are at a higher risk of being hospitalized and placed on a mechanical ventilator for COVID-19 than patients with a normal body weight. We discuss the pathophysiology behind this relationship and the implications in the global fight against COVID-19.
\end{abstract}

Keywords: COVID-19; coronavirus; obesity; cardiometabolic syndrome.

No one single mechanism is responsible for disease progression into severity in COVID-19 cases as in almost all diseases -chronic or not, transmissible or not-. We as scientists are trained to observe, identify differences and similarities between cases and arrive at possible explanations called hypothesis that can help the scientific community to develop effective strategies to combat the illness.

To this day several factors have been identified and when put together they tell a storyline that sums up the pathophysiology of severity in COVID-19 shown in Figure 1.

But how does this scenario come to be? The answer comes from a previous pandemic that has been around for many years: the Cardiometabolic Syndrome (CMS) pandemic. CMS is defined by a combination of metabolic disorders that include diabetes mellitus, systemic arterial hypertension, central obesity, and dyslipidemia. All these conditions lead to elevated heart disease risk, which in turn is the leading cause of death in first world countries and doesn't fall far behind in the rest of the world as well. This global epidemic to some doesn't seem so scary being that it cannot be transmitted through droplets or by touching "infected" surfaces. This idea, however, isn't completely true. The first risk factor for this group of diseases is being overweight or obesity, and this is in a sense "transmitted". Eating habits are a cultural phenomenon, and from one generation to the next, families and communities pass on grocery lists, recipes and pantry contents. As of 2019 the global mean prevalence of obesity was measured at $19.5 \%$. This number has almost tripled since 1975 and is currently the number one risk factor associated with premature death. Obesity as a risk factor for disease usually means it leads to chronic diseases such as the ones previously mentioned, but nowadays we are observing a different consequence of being overweight. An elevated body mass index has become a highrisk factor for severity in COVID-19 cases. [2]

Table 1 shows the evidence on the previous statement. A study by Zheng et al of 214 patients in Wuhan, China with laboratory confirmed COVID-19 showed that the presence of

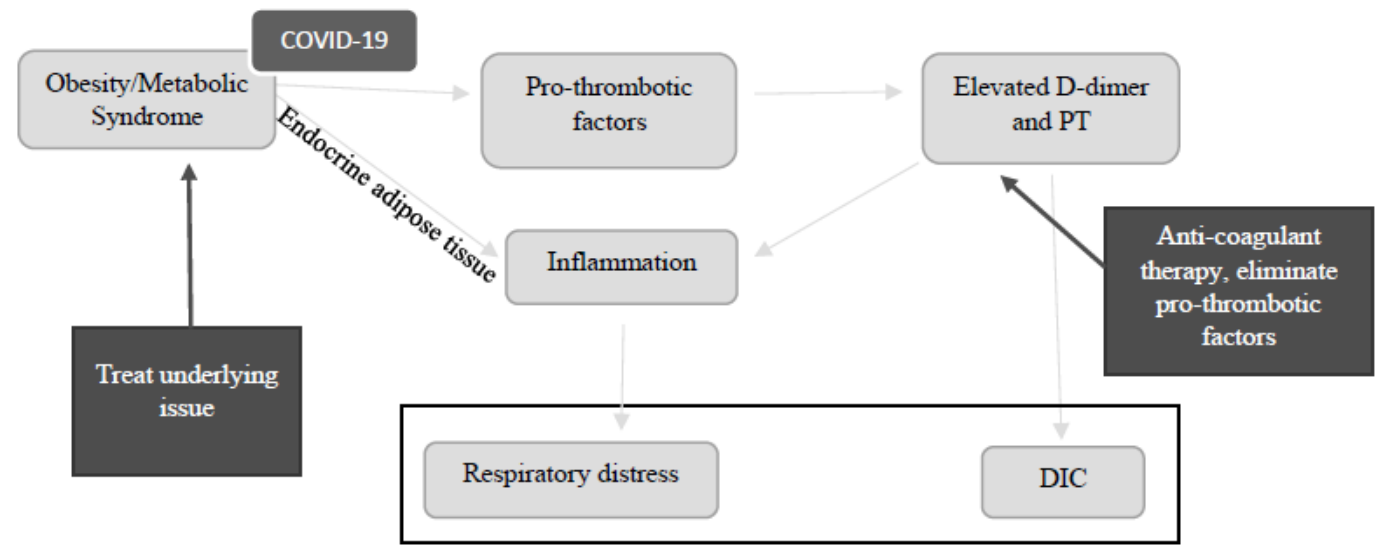

Figure 1. Schematic representation of shared pathophysiology in COVID-19 cases with underlying metabolic illness. [1]. DIC: Disseminated Intravascular Coagulation. 
Table 1: Epidemiological studies on COVID-19 outcomes and obesity related risk-factors

\begin{tabular}{|c|c|c|}
\hline Author, Region and Date & Subjects & Findings \\
\hline $\begin{array}{l}\text { Z. Wu [7] } \\
\text { Mainland China } \\
\text { Updated Feb 11, } 2020\end{array}$ & $\begin{array}{l}\text { 72,314 suspicious cases of COVID-19 } \\
44,672 \text { lab-confirmed cases }\end{array}$ & $\begin{array}{l}2.3 \% \text { Case-Fatality Rate } \\
\text { Mild cases } 81 \% \\
\text { Severe cases } 14 \% \\
\text { Critical cases } 5 \%\end{array}$ \\
\hline $\begin{array}{l}\text { S. Garg [8] } \\
\text { USA (COVID-NET) } \\
\text { March } 1-30,2020\end{array}$ & 1,482 hospitalized patients & $\begin{array}{l}89 \% \text { of patients had one or more underlying conditions: } \\
\text { Hypertension } 49.7 \% \\
\text { Obesity } 48.3 \% \\
\text { Chronic lung disease } 34.6 \% \\
\text { Diabetes Mellitus } 28.3 \% \\
\text { Cardiovascular disease } 27.88 \% \\
\text { Among patients } 18-49 \text { years-old obesity was the most prevalent underlying condition (59\%). }\end{array}$ \\
\hline $\begin{array}{l}\text { P. Goyal [9] } \\
\text { New York City, US } \\
\text { Mar 3-27, } 2020\end{array}$ & $\begin{array}{l}\text { First } 393 \text { cases of COVID-19 adults hospitalized } \\
\text { in New York }\end{array}$ & $\begin{array}{l}\text { Patients who required invasive mechanical ventilation were more likely to be male, have obesity and } \\
\text { elevated liver-function and inflammatory markers. }\end{array}$ \\
\hline $\begin{array}{l}\text { S. Richardson [10] } \\
\text { New York, USA } \\
\text { Mar } 1 \text { - Apr 4, } 2020\end{array}$ & 5,700 hospitalized patients & $\begin{array}{l}\text { Most common comorbidities among hospitalized patients: } \\
\text { Hypertension } 56.6 \% \\
\text { Obesity } 41.7 \% \text { - (Morbid obesity } 19 \% \text { ) } \\
\text { Diabetes Mellitus } 33.8 \%\end{array}$ \\
\hline $\begin{array}{l}\text { G. Grasselli [11] } \\
\text { Milan, Italy } \\
\text { Feb } 20 \text { - Mar 18, } 2020\end{array}$ & 73 patients in intensive care unit & $\begin{array}{l}\text { Over } 80 \% \text { of patients in ICU were overweight or had obesity. } \\
\text { Normal weight }-19 \% \\
\text { Overweight }-51.9 \% \\
\text { Obesity } 1-15.4 \% \\
\text { Obesity } 2-11.5 \% \\
\text { Obesity } 3-1.9 \%\end{array}$ \\
\hline $\begin{array}{l}\text { Zheng [3] } \\
\text { Wenzhou, China } \\
\text { Jan } 1 \text { - Feb 29, } 2020 \\
\end{array}$ & $\begin{array}{l}214 \text { patients with lab confirmed COVID-19 } \\
\text { Ages } 18-75\end{array}$ & $\begin{array}{l}\text { A BMI equal to or greater than } 25 \mathrm{~kg} / \mathrm{m}^{2} \text { was associated with a } 6 \text {-fold increased risk of severe illness. } \\
\text { This risk remained significant even after adjusting for age and other comorbidities. }\end{array}$ \\
\hline $\begin{array}{l}\text { Petrilli [4] } \\
\text { New York } \\
\text { Mar 1 - Apr 7, } 2020 \\
\end{array}$ & $\begin{array}{l}4,103 \text { cases of COVID-19 } \\
1,999 \text { hospitalized }\end{array}$ & $\begin{array}{l}\text { The chronic condition with the strongest association to critical illness was obesity. } \\
39.8 \% \text { of hospitalized patients had obesity. }\end{array}$ \\
\hline $\begin{array}{l}\text { Qingxian [12] } \\
\text { Mainland China } \\
\text { Jan } 11 \text { - Feb 16, } 2020 \\
\end{array}$ & 383 patients admitted to a hospital in Shenzen & $\begin{array}{l}\text { After adjusting for age, sex, disease history and treatment the overweight group was } 2.42 \text { times more } \\
\text { likely to develop severe pneumonia. }\end{array}$ \\
\hline $\begin{array}{l}\text { A. Simonnet [5] } \\
\text { Lille, France } \\
\text { Feb } 27 \text { - Apr 5, } 2020\end{array}$ & $\begin{array}{l}124 \text { patients admitted to ICU for COVID- } 19 . \\
\text { Compared to control group from } 2019\end{array}$ & $\begin{array}{l}\text { Obesity was significantly more frequent among cases of COVID-19 (47.6\%) compared to control group } \\
(25.2 \%) \text {. } \\
\text { The median BMI of patients requiring intubation was } 31.1 \mathrm{~kg} / \mathrm{m}^{2} \text { compared to } 27 \mathrm{~kg} / \mathrm{m}^{2} \text { in the patients } \\
\text { who did not require intubation. } \\
\text { In individuals with a BMI } \geq 35 \mathrm{~kg} / \mathrm{m}^{2} \text { the odds ratio for intubation was } 7.36 \text { compared to individuals } \\
\text { with a normal BMI. }\end{array}$ \\
\hline
\end{tabular}

a Body Mass Index $(\mathrm{BMI})>25 \mathrm{~kg} / \mathrm{m}^{2}$ was associated with a near- 6 fold increased risk of severe illness, even after adjusting for age and other comorbidities. [3] Of 4,103 COVID-19 cases in New York City the chronic condition which conferred the strongest association with critical illness was obesity, with $39.8 \%$ of hospitalized patients having obesity. [4]

Among 124 patients admitted for COVID-19 to a hospital in Lille, France $47.6 \%$ had obesity. Patients with a BMI of greater than $35 \mathrm{~kg} / \mathrm{m}^{2}$ were 7.36 times more likely to require a ventilator than patients with a BMI of less than $25 \mathrm{~kg} / \mathrm{m}^{2}$. [5] In Milan more than $80 \%$ of 73 patients treated in an ICU were overweight or had obesity, when the rates of overweigh and obesity in Italy are only $35.4 \%$ of the population. [6]

Two main explanations play a role in this complicated infectious disease in association with weight problems. The first one is the chronic inflammatory state it conveys. Recent studies have found that adipose tissue secretes extracellular vesicles that function as vectors which can modify cellular function in the recipient through the information they carry. Data suggests that this mechanism is used by fat to induce monocyte differentiation into active macrophages and high secretion of IL-1 and TNF- $\alpha$ among other cytokines. [13] The second one is the fact that patients with obesity have been found to have higher concentrations of pro-thrombotic factors as compared to normal-weight controls. Some of these altered parameters include higher D-dimer, fibrinogen and factor VII; as well as lower fibrinolysis because of higher plasminogen activator inhibitor-1. [14]

Besides increased inflammatory cytokines, obesity englobes several pathophysiological factors which affect the risk and outcomes of patients with COVID-19. In the respiratory tract obesity may cause pulmonary restriction, decreased pulmonary volumes and ventilation-perfusion mismatching. Patients with obesity are more likely to present diabetes mellitus and atherosclerosis which may be complicated by COVID-19. Additionally, there is limited data on the right dosing of antimicrobials in obesity and bioavailability of drugs used to treat patients with this disease may be affected by altered protein binding, metabolism and volume of distribution. [15]

On the other hand, new information is developing every day concerning COVID-19 cases and more data is suggesting that bad prognosis is linked to thromboembolic events caused 
by inflammation, hypoxia and coagulation abnormalities. One study by Klok et al studied 184 Intensive Care Unit (ICU) patients with confirmed COVID-19, and found that $31 \%$ showed thrombotic complications, of which $81 \%$ was due to pulmonary embolism. [16] When we put two and two together, the relationship becomes apparent. Obesity is a clear catalyzer for severe COVID-19 cases. In a country like Mexico, where the prevalence for overweight and obesity in over 20-year-olds is $75.2 \%$, this relationship is very threatening. [17]

It seems that the best way to prevent bad outcomes from this novel disease (as well as from infectious diseases in general) is to be in good health prior to contracting it in the first place. As for those patients who already suffer from CMS or one of its components, preventive treatment is our main recommendation. These patients should be at optimal glycemic, systemic arterial pressure and cholesterol level goals. A study by Carter et al also suggests that vitamin $\mathrm{D}$ deficiencies (also more common in patients with obesity) have been linked to worse cytokine storms. To this end, physical activity as well as sun exposure is effective ways to boost vitamin D levels. [18]

This sound reasonable, right? Well, reasonable doesn't always mean achievable in all populations. Vulnerable communities around the world are struggling every day just to have access to general medical attention. These communities are also at an increased risk of exposure to COVID-19. Working from home is a privilege that is unavailable for many people from a lower socio-economic status. Social distancing is considerably more difficult for people living in overcrowded neighborhoods. Emerging epidemiological studies in the U.S. suggest a disproportionate burden of illness and higher death rates among minority groups. [9]

Currently there is no gold standard treatment for COVID-19, however, all this data suggests that global efforts need to be directed towards prevention and education. Preexisting conditions need to be under control and lifestyle habits should be aimed towards getting enough exercise and a proper nutrition. $[19,20]$

\section{References}

1. Xiong M, Liang X, Wei YD (2020) Changes in Blood Coagulation in Patients with Severe Coronavirus Disease 2019 (COVID-19): A Meta-Analysis. Br J Haematol. [crossref]

2. Blüher M (2019) Obesity: global epidemiology and pathogenesis. Nat Rev Endocrinol 15: $288-298$.
3. Zhou F, Yu T, Du R, Fan G, Liu Y et al. (2020) Clinical course and risk factors for mortality of adult inpatients with COVID-19 in Wuhan, China: a retrospective cohort study. The Lancet. 395: 1054-1062. [crossref]

4. Petrilli CM, Jones SA, Yang J, Rajagopalan H, O'Donnell LF, Chernyak Y, Horwitz LI (2020) Factors associated with hospitalization and critical illness among 4,103 patients with COVID-19 disease in New York City. medRxiv.

5. Simonnet A, Chetboun M, Poissy J, Raverdy V, Noulette J et al. (2020) Intensive Care COVID-19 and Obesity study group. High prevalence of obesity in severe acute respiratory syndrome coronavirus-2 (SARS-CoV-2) requiring invasive mechanical ventilation. Obesity. [crossref]

6. Zangrillo A, Beretta L, Scandroglio AM, Monti G, Fominskiy E (2020) Characteristics, treatment, outcomes and cause of death of invasively ventilated patients with COVID-19 ARDS in Milan, Italy. Crit Care Resusc. [crossref]

7. Wu Z, McGoogan JM (2020) Characteristics of and important lessons from the coronavirus disease 2019 (COVID-19) outbreak in China: summary of a report of 72 314 cases from the Chinese Center for Disease Control and Prevention. Jama. [crossref]

8. Garg S (2020) Hospitalization rates and characteristics of patients hospitalized with laboratory-confirmed coronavirus disease 2019-COVID-NET, 14 States, March 1-30, 2020. MMWR. Morbidity and Mortality Weekly Report 69.

9. Goyal P, Choi JJ, Pinheiro LC, Schenck EJ, Chen R, Jabri A, Hoffman KL (2020) Clinical Characteristics of Covid-19 in New York City. New England Journal of Medicine.. [crossref]

10. Richardson S, Hirsch JS, Narasimhan M, Crawford JM, McGinn T et al. (2020) Presenting Characteristics, Comorbidities, and Outcomes Among 5700 Patients Hospitalized With COVID-19 in the New York City Area. JAMA. [crossref]

11. Grasselli G, Zangrillo A, Zanella A, Antonelli M, Cabrini L et al. (2020) Baseline characteristics and outcomes of 1591 patients infected with SARS-CoV-2 admitted to ICUs of the Lombardy Region, Italy. Jama. [crossref]

12. Qingxian C, Fengjuan C, Fang L, Xiaohui L, Tao W et al. (2020) Obesity and COVID-19 severity in a designated hospital in Shenzhen, China. China.

13. Kim A, Shah AS, Nakamura T (2018) Extracellular Vesicles: A Potential Novel Regulator of Obesity and Its Associated Complications. Children 5: 152. [crossref]

14. De Pergola G, Pannacciulli N (2002) Coagulation and fibrinolysis abnormalities in obesity. J Endocrinol Invest 25: 899-904. [crossref]

15. R Huttunen, J Syrja"nen (2013) Obesity and the risk and outcome of infection. International Journal of Obesity 37: 333-340. [crossref]

16. Klok FA, Kruip MJHA, van der Meer NJM, Arbous MS, Gommers DAMPJ et al (2020) Incidence of thrombotic complications in critically ill ICU patients with COVID-19. Thrombosis Research. [crossref]

17. Romero-Martínez M, Shamah-Levy T, Vielma-Orozco E, Heredia-Hernández $\mathrm{O}$ Mojica-Cuevas J et al. (2019) Encuesta Nacional de Salud y Nutrición (Ensanut 2018): metodología y perspectivas. salud pública de México 61: 917-923.

18. Carter SJ, Baranauskas MN, Fly AD (2020) Considerations for obesity, vitamin D, and physical activity amidst the COVID-19 pandemic. Obesity.

19. Smith JA, Judd J (2020) COVID-19: Vulnerability and the power of privilege in a pandemic. Health Promotion Journal of Australia 31: 158. [crossref]

20. Ahmed F, Ahmed NE, Pissarides C, Stiglitz J (2020) Why inequality could spread COVID-19. The Lancet Public Health 5: 240. [crossref] 